\title{
Trzy typy teorii znaczenia
}

\section{Janusz Maciaszek}

Uniwersytet Łódzki

\section{Wstęp}

Znaczenie wyrażenia językowego jest podstawowym, ale zarazem niezwykle tajemniczym pojęciem filozofii języka. Celem tego rozdziału jest przedstawienie niektórych problemów, przed którymi stajemy, próbując wyjaśnić i uściślić to pojęcie, czyli próbując zbudować teorię znaczenia1. Próby rozwiązania tych problemów prowadzą, moim zdaniem, do wyróżniania trzech możliwych typów teorii.

Z intuicyjnego punktu widzenia znać znaczenie wyrażenia, to nic innego jak je rozumieć. Jak się okaże, termin „rozumienie” nie musi być traktowany jako „chwytanie” jakiegoś bytu, z którym utożsamiamy znaczenie ${ }^{2}$. Zrozumieć wyrażenie, jak podkreślał wielokrotnie Dummett, to nic innego niż „uchwycić” trzy aspekty znaczenia, które Frege nazwał sensem, mocą i tonem. Te trzy aspekty rozumienia można wyróżnić już na poziomie refleksji przedteoretycznej. Pierwszy z nich dotyczy opisowej (treściowej) funkcji języka. Przez sens wyrażenia będziemy mogli wstępnie rozumieć to coś, dzięki czemu wyrażenie językowe posiada odniesienie. Drugi aspekt rozumienia wyrażenia dotyczy funkcji performatywnej, a trzeci funkcji emotywnej. Przez teorię znaczenia rozumie się tradycyjnie teorię sensu ${ }^{3}$.

Termin „teoria” bywa używany bardzo różnie, począwszy od ścisłego rozumienia tego terminu w matematyce i logice, aż po luźne rozumienie w naukach humanistycznych. W sensie ścisłym teoria to zbiór twierdzeń (w języku sztucznym), domknięty ze względu na relację wynikania 4 W sensie luźniejszym przez teorię rozumiemy zbiór zdań, które opisują jakiś „fragment rzeczywistości” i — co najważniejsze — opisują

1 Tekst ten jest oparty na mojej monografii Znaczenie, prawda, przekonania, Maciaszek (2008), szczególnie na rozdziale IV. Przedstawione tu rozważania mieszczą się całkowicie w tradycji logicznofilozoficznej z pominięciem tradycji filologicznej.

2 Popularne w filozofii języka określenie „chwytać znaczenie” wprowadził Frege. Sam Frege utożsamiał znaczenie z pewnym bytem abstrakcyjnym. Będzie o tym mowa w dalszej części rozdziału.

3 Tak też teoria znaczenia będzie zazwyczaj rozumiana w tym opracowaniu, przy czym znaczenie nie musi być identyfikowane ze specyficznym rozumieniem sensu u Fregego. 
pewne prawidłowości zachodzące w owej rzeczywistości. Mówiąc o teoriach znaczenia, mam na myśli to drugie, luźniejsze rozumienie terminu „teoria”.

Kiedy mówimy o teorii znaczenia, mamy na myśli określony język, np. język teorii naukowej lub język naturalny. Kazimierz Ajdukiewicz w Metodologicznych typach nauk wyróżnił trzy typy nauk, opierając się na charakterze ich przesłanek ostatecznych (zob. Ajdukiewicz, 1960, 287-316). W przypadku nauk apriorycznych, czyli matematycznych oraz logiki formalnej, przesłankami ostatecznymi są zdania pewne (aksjomaty) przyjęte a priori, tj. niezależnie od doświadczenia. W przypadku nauk empirycznych za przesłanki ostateczne dodatkowo przyjmuje się zdania a posteriori, tj. zdania oparte na doświadczeniu. W naukach humanistycznych, oprócz zdań przyjętych a priori i a posteriori, za przesłanki ostateczne uznaje się zdania będące rezultatem rozumienia innych ludzi. Rozumienie innych ludzi jest możliwe dzięki różnym świadectwom. Należą do nich zachowania pojedynczych osób i całych grup, wytwory sztuki, przedmioty codziennego użytku, zwyczaje oraz towarzyszące im wypowiedzi i napisy. Zrozumieć słowa drugiego człowieka, to przypisać jego działaniom językowym pewne intencje lub motywy, przypisać mu cele i wartości, zrozumieć, jak mówiący postrzega świat, czego pragnie i jaki jest jego emocjonalny stosunek do innych ludzi, rzeczy i zdarzeń. Teoria znaczenia dla języków humanistyki oraz języka naturalnego powinna uwzględniać bogactwo świadectw, na których opieramy się, przypisując znaczenia słowom innych ludzi.

Teoria znaczenia języków nauk apriorycznych i empirycznych powinna być zdecydowanie prostsza od teorii znaczenia języka naturalnego, gdyż należy w niej uwzględnić znacznie uboższy zakres świadectw, np. wybór aksjomatów i reguł inferencji oraz zdań opisujących dane obserwacji lub eksperymentu. Teoria znaczenia dla języka naturalnego powinna dać się zatem redukować do teorii znaczenia języków teorii naukowych. Historia refleksji filozoficznej nad znaczeniem wskazuje jednak, że próby budowania teorii znaczenia przebiegały w kierunku przeciwnym. Zazwyczaj budowano teorię dla wąskiego języka teorii naukowej, licząc jednocześnie na to, że będzie ona „pasowała” do języka naturalnego lub jego uściślonej wersji. Okazywało się jednak, że nadzieje te były płonne — żadna z klasycznych teorii nie nadawał się na teorię znaczenia języka naturalnego lub języka humanistyki.

Bardzo często w nazwie teorii zawarta jest informacja, o czym jest ta teoria i co stanowi jej przedmiot. Teorie znaczenia oparte na definicji wyraźnej terminu „znaczenie" gwarantowały istnienie znaczenia jako pewnego obiektu, gdyż utożsamiały je z pewnym wyobrażeniem (asocjacjonizm) lub zespołem cech (teoria konotacyjna) ${ }^{5}$. W przypadku teorii, które nie opierają się na definicjach wyraźnych, np. teoriach matematycznych, które podają sens pewnych terminów w kontekście aksjomatów, nie ma zazwyczaj zgody co do sposobu istnienia obiektów, które oznaczają owe terminy. Określenie „sposób istnienia” pochodzi od Romana Ingardena, który w O dziele literackim (zob. Ingarden, 1931) opisał dokładnie charakterystykę ontologiczną sposobu istnienia bohatera fikcyjnego jako bytu czysto intencjonalnego. Arytmetyka, rozumiana jako teoria liczb naturalnych, musi nam podać znaczenie terminu „liczba naturalna” i znaczenia poszczególnych liczebników. Jej celem nie jest podanie charakterystyki ontologicznej liczb jako bytów pewnego rodzaju. Budując teorię zna-

5 Asocjacjonizm oraz teorię konotacyjną omówię nieco dalej. 
czenia, należy mieć świadomość tego, czy czynione założenia natury ontologicznej i filozoficznej na temat znaczenia nie wpływają na kształt tej teorii ${ }^{6}$.

Poza założeniami ontologicznymi, na kształt teorii znaczenia wpływała zazwyczaj próba odpowiedzi na pytanie, czego oczekuje się od tej teorii. Zdaniem autora teoria znaczenia ma wyjaśniać zachowania językowe, w tym sensie, że powinna opisywać ich warunki, możliwości, nie zaś ich mechanizm. Powinna być zatem, o ile można użyć takiego zwrotu, „teorią filozoficzna”, nie zaś filologiczną czy psychologiczną.

W tym momencie stajemy przed kolejnym problemem. Jakie zachowania i zjawiska językowe powinna móc wyjaśniać teoria znaczenia? Odpowiedź na to pytanie nie jest wcale oczywista. Ogólnikowe określenie „zachowanie językowe” wymaga z pewnością uściślenia. Każda teoria, nawet w luźnym sensie, stanowi bowiem pewną idealizację i nie opisuje rzeczywistości w całej jej złożoności, lecz wybiera interesujące nas aspekty, pomijając inne. Teoria znaczenia nie może być zatem teorią wszelkich zjawisk i zachowań językowych. W kolejnych paragrafach przyjrzymy się różnym poglądom na temat tego, jakie zjawiska językowe powinna wyjaśniać teoria znaczenia. Ponieważ filozofia języka rozwinęła się na gruncie badań nad językami teorii naukowych, a dopiero wtórnie objęła swoim zainteresowaniem język naturalny, najwcześniejsze teorie znaczenia próbowały wyjaśnić przede wszystkim poznawczą funkcję języka.

Przyjrzymy się kolejno trzem typom teorii znaczenia - będą to kolejno teorie trywialne, oparte na definicji wyraźnej terminu „znaczenie”, u podstaw których leżą wyraźne założenia ontologiczne; teorie, w których nie operuje się definicją wyraźną terminu „znaczenie”, lecz termin ten występuje w uznawanych na gruncie tych teorii postulatach oraz teorie, które nie operują w ogóle terminem „znaczenie”. Pierwszy typ teorii będzie omawiany w paragrafie 2. Kolejny - w paragrafie poświęconym Fregemu. W ostatnich paragrafach tego rozdziału zostanie przedstawiony i przedyskutowany trzeci typ teorii.

\section{Arystoteles i jego interpretatorzy}

Wzorując się na Platonie, Arystoteles utożsamił znaczenie nazwy gatunkowej z formą (ideą) rzeczy. Zarówno poznanie naukowe, jak i potoczne możliwe było dzięki bezpośredniemu uchwyceniu formy przez umysł. Dzięki temu nazwa gatunkowa oznaczała gatunek (przedmiot idealny ${ }^{7}$ ) i mogła być orzekana o poszczególnych przedstawicielach tego gatunku. Sformułowana w szczątkowej postaci teoria znaczenia Arystotelesa przypisywała zatem znaczeniom nazw charakter idealny, a zarazem pojęciowy. ${ }^{8}$ Połączenie tych dwóch funkcji decydowało o tym, że znaczenie nie tylko umożliwiało po-

6 Nawet w przypadku teorii pozamatematycznych kształt teorii nie rozstrzyga sposobu istnienia przedmiotów, o których jest ta teoria. Za przykład może nam posłużyć teologia. Najbardziej zagorzały ateista, który twierdzi, że Boga nie ma, faktycznie głosi jedynie, że Bóg istnieje w inny sposób niż utrzymują to teiści. Dla ateisty Bóg istnieje bowiem jako fikcyjny bohater Biblii. Nic nie stoi jednak na przeszkodzie, aby ateista był kompetentnym teologiem.

7 Gatunku w sensie Arystotelesa nie można utożsamiać ze zbiorem indywiduów. Indywidua bowiem powstają i giną, gatunek zaś jest wieczny i niezmienny. W konsekwencji Arystoteles był zagorzałym wrogiem pojawiających się w starożytności naiwnych teorii ewolucji gatunków.

8 Próbę rekonstrukcji teorii znaczenia Arystotelesa przeprowadzam w Maciaszek, 2008, 72-86. 
znanie naukowe, ale było przedmiotem poznania naukowego, ponieważ nauka badała nie poszczególne rzeczy, lecz ich formy. Funkcja poznawcza znaczenia, a w konsekwencji funkcja poznawcza języka naukowego u Arystotelesa, wyznaczyła kształt teorii znaczenia aż do końca XIX wieku. W średniowieczu prowadziło to do sporów interpretacyjnych dotyczących między innymi natury powszechników, np. gatunków. ${ }^{9}$

Bezpośrednią konsekwencją podejścia Arystotelesa był pokutujący do czasów współczesnych podział wyrażeń na kategorematyczne, które posiadają znaczenia, i synkategorematyczne, które znaczeń nie posiadają. Samodzielną funkcję poznawczą pełnić mogły jedynie wyrażenia kategorematyczne, wyrażenia synkategorematyczne pełniły jedynie funkcję pomocniczą czy wręcz składniową. Wyrażenia synkategorematyczne nie posiadają bowiem łatwego do uchwycenia odniesienia. Znaczenia miały bowiem stanowić łącznik między słowem a jego odniesieniem. ${ }^{10}$

Swoistą interpretacją teorii znaku Arystotelesa był tzw. konceptualizm, który w przypadku teorii znaczenia nosił nazwę asocjacjonizmu. Asocjacjoniści, szczególnie J. Locke i D. Hume, utożsamili znaczenie nazwy z tzw. idea skojarzoną z ową nazwą (zob. Locke, 1955, 13-36). Idea była bytem mentalnym — pewnym wyabstrahowanym wyobrażeniem typowego przedstawiciela gatunku. Tak rozumiane znaczenia nazwy umożliwiało w wielu przypadkach rozpoznanie jej odniesienia.

Oczywiście nie wszystkie nazwy, z którymi skojarzone są wyobrażenia, tj. nazwy znaczące, mają odniesienia przedmiotowe. Umysł jest jednak w stanie dokonywać operacji na ideach. W rezultacie powstają idee złożone, które są znaczeniami tzw. nazw pustych, np. „złota góra” (zob. Hume, 1977, 24-26). Myślenie to zatem operowanie na ideach, czyli na znaczeniach słów. Dzięki słowom idee te można komunikować innym ludziom. Komunikacja językowa opiera się zatem na dwóch poznawczych funkcjach języka. Pierwsza z nich polega na wyznaczaniu odniesienia przedmiotowego nazw, druga na operacjach na ideach, czyli na znaczeniach wyrażeń. Pierwsza funkcja jest całkowicie bierna i receptywna, chociaż zapewnia odniesienie przedmiotowe wyrażeń. Druga funkcja pozwala na świadome operowanie językiem — pozwala na przykład wymyślać fikcję literacką — ale musi pozostawać w zgodzie z funkcją pierwszą. Nie można bowiem mieć idei (czyli wyobrażenia) kwadratowego koła lub trójkątnego czworoboku. Byłyby to wyrażenia pozbawione znaczeń, które nie pełnią w poznaniu jakiejkolwiek roli.

Za inną interpretację arystotelizmu można uznać teorię konotacyjną J. S. Milla (zob. Mill, 1962, 38-71). Celem tej teorii było przede wszystkim wyjaśnienie możliwości budowania trafnej, empirycznej wiedzy o świecie. Wiedza ta miała postać praw naukowych, formułowanych za pomocą zdań ogólnych, wyprowadzanych ze zdań opisujących dane doświadczenia, za pomocą indukcji. Pojedynczy obiekt, np. określony człowiek, może być arbitralnie nazwany za pomocą pewnej nazwy własnej. Upraszczając nieco sprawę, można powiedzieć, że jedynym powodem określania go daną nazwą jest czyjaś decyzja, aby dane indywiduum ową nazwą określić. Nazwy gatunkowe, chociaż ich kształt fizyczny jest z pewnością umowny, nie są stosowane arbitralnie i dlatego pojawiają się w prawach naukowych. $Z$ tego też powodu poznaw-

9 Na zamęt w tej kwestii wpływało również to, że zazwyczaj nie odróżniano tzw. bytów idealnych od idei, czyli formy gatunkowej od gatunku.

10 Dzięki temu, że mamy w umyśle formę psa, czyli znaczenie słowa „pies”, możemy rozpoznawać (typowych) przedstawicieli tego gatunku. 
cza funkcja języka sprowadza się u Milla do zapewnienia odniesienia przedmiotowego nazwom ogólnym. Aby wyjaśnić tak rozumianą funkcję poznawczą, należy odpowiedzieć na pytanie, dlaczego dane słowo odnosi się do danej rzeczy, czyli denotuje ową rzecz. Odpowiedź Milla była następująca: słowo denotuje rzecz, gdyż konotuje istotne ze względu na owo denotowanie cechy owej rzeczy.

Wprowadzenie pojęcia konotacji nazwy, jako jej znaczenia, nie byłoby konieczne, gdyby nie to, że te same rzeczy mogą być oznaczone przez różne nazwy. Użycie tej, a nie innej nazwy do oznaczenia danej rzeczy, pełni zatem bardzo ważną funkcję w poznaniu ludzkim. Funkcję tę zapewnia znaczenie nazwy — pewien czynnik związany z daną nazwą i sprawiający, że mimo, iż dwie nazwy mogą to samo oznaczać, pełnią zupełnie inną funkcję $\mathrm{w}$ naszym poznaniu. ${ }^{11}$

Omówione tu teorie znaczenia są przykładami trywialnych teorii pierwszego typu. Ich motywacja miała przede wszystkim charakter ontologiczny. Z punktu widzenia poznawczej funkcji języka, ich celem było formułowanie prostych praw ogólnych, w których występują nazwy gatunkowe. Dla Arystotelesa paradygmatyczna nauką była bowiem biologia. W konsekwencji podstawową wadą tych teorii było to, że były one ograniczone jedynie do tych nazw. ${ }^{12}$ Kolejna teoria znaczenia nie ograniczała się do nazw ogólnych, gdyż dla jej twórcy paradygmatyczną nauką była matematyka.

\section{Teoria sensu Fregego i jej interpretacje}

Frege, podobnie jak wszyscy filozofowie języka, którzy punktem wyjścia swoich teorii znaczenia uczynili rolę języka w poznaniu naukowym, rolę znaczenia upatrywał przede wszystkim w ustalaniu odniesienia wyrażeń. Frege, w odróżnieniu od Milla, nie ograniczał swojej teorii sensu do nazw gatunkowych. Poznawczą funkcję pełniły u niego również sensy nazw własnych, wyrażeń różnych kategorii syntaktycznych oraz sensy zdań. Teoria sensu Fregego była również pierwszą teorią nietrywialną, w której nie podaje się definicji wyraźnej terminu „znaczenie”.

Teoria sensu Fregego jest wyznaczona przez szereg postulatów na temat znaczenia, rozrzuconych w jego pismach semantycznych. Biorąc pod uwagę ogromną ilość rozbieżnych interpretacji pojęcia sensu, istnieją podstawy, aby sądzić, że postulaty te są nie do pogodzenia. W tym rozdziale skupić się na dwóch słynnych postulatach na temat znaczenia. Pierwszy z nich pojawia się w kontekście analizy mowy zależnej w artykule Sens i znaczenie (zob. Frege, 1977, 60-88). Prowadzi on do konstatacji, że sens u Fregego jest szczególnym rodzajem odniesienia, poczynione zaś w artykule Myśl. Studium logiczne (zob. Frege, 1977, 101-129) uwagi skłaniają do interpretacji sensu jako bytu idealnego. W innych miejscach sens bywa jednak charakteryzowany metaforycznie jako droga prowadząca do odniesienia, a w przypadku zdania - droga do jego wartości logicznej. Odniesieniem zdania oznajmującego jest bowiem jego wartość logiczna — zdania oznajmujące są nazwami dwóch obiektów: Prawdy i Fałszu13.

11 Na przykład nazwy „największe miasto w Polsce” i ,stolica Polski”.

12 Doskonałą krytykę tych teorii przeprowadził Ajdukiewicz w O znaczeniu wyrażeń (zob. Ajdukiewicz, 1960, 102-136).

13 Z kolei zdania o fikcji literackiej są, zdaniem Fregego, pozbawione wartości logicznych. Mają one jednak sensy. 
W tym miejscu dochodzimy zatem do kolejnego postulatu Fregego: sens wyrażenia decyduje o wartości poznawczej zdania, w którym to wyrażenie występuje. W odróżnieniu $A=A$, zdanie identycznościowe postaci $A=B$, np. „Gwiazda poranna to Gwiazda wieczorna”, stwierdzające identyczność odniesień dwóch nazw jednostkowych (w szczególności nazw własnych) niesie z sobą bardzo ważną i niebanalną informację. Ponieważ roli tej nie mogą pełnić odniesienia, bo są tym samym obiektem, ani same kształty fizyczne wyrażeń, nośnikiem wartości poznawczej jest sens.

Analiza mowy zależnej opiera się na zasadzie zwanej obecnie prawem zastępowania ekstensjonalnego, która — zdaniem Fregego — bezwzględnie w języku obowiązuje. Jeśli w wyrażeniu złożonym (np. zdaniu) zastąpimy jego część (np. zdanie podrzędne) wyrażeniem o tym samym odniesieniu, to odniesienie całości (w przypadku zdania jest to jego wartość logiczna) nie ulega zmianie. Rzeczywistość bowiem nie zależy od tego, jak ją opisujemy. Załóżmy, że Małgosia nie wie, że jej narzeczony Jaś jest najgorszym studentem UŁ. Nazwy „Jaś” i „najgorszy student UŁ” oznaczają ten sam obiekt, lecz posiadają różne sensy. Jeżeli w zdaniu prawdziwym „Małgosia chodzi z Jasiem” zamienimy słowo "Jaś" na „najgorszy student UŁ”, to otrzymamy zdanie prawdziwe „Małgosia chodzi z najgorszym studentem UŁ”. Jeśli jednak dokonamy tego samego manewru w prawdziwym zdaniu „Małgosia wie, że Jaś jest jej narzeczonym”, to otrzymamy zdanie fałszywe „Małgosia wie, że najgorszy student UŁ jest jej narzeczonym”. W pierwszym przypadku zasada Fregego obowiązuje, w drugim przypadku zdaje się załamywać. Aby wybrnąć z tej trudności i ocalić swoją zasadę, Frege twierdzi, że w pewnych kontekstach odniesieniami wyrażeń są ich sensy - w takim przypadku drugi przykład nie przeczy zasadzie, gdyż nie mamy w nim do czynienia z zamiana wyrażeń o tym samym odniesieniu. Sensy są zatem specjalnymi odniesieniami, co przesądza o ich bytowym charakterze. Ponieważ nie są to byty fizyczne, należy przypisać im status bytów abstrakcyjnych, a nawet idealnych.

Gdyby sensy Fregego interpretować jako byty idealne, trudno utożsamić by je było ze znaczeniami językowymi, gdyż należałoby zaakceptować absurdalny wniosek, że znaczenia wszystkich możliwych słów bytują wiecznie i niezmiennie, bez względu na to, czy słowa, które im odpowiadają faktycznie są używane w jakimkolwiek języku14. Znaczenia słów języka mają niewątpliwie charakter intersubiektywny, lecz z pewnością nie są wieczne i niezmienne. Przeciwnikiem utożsamiania sensów ze znaczeniami językowymi jest znany interpretator Fregego - T. Burge, który z kolei interpretuje je jako byty idealne (zob. Burge, 2005).

Jeżeli jednak, jak chce tego Dummett, sensy Fregego utożsamimy ze znaczeniami językowymi, to pociąga to za sobą określone konsekwencje. Przede wszystkim znaczenia, których nie można utożsamić z bytami idealnymi, muszą być $\mathrm{w}$ pewien sposób związane z wiedzą i przekonaniami członków wspólnoty językowej. Pełnią one zatem funkcję poznawczą w sensie znacznie szerszym niż ustalanie odniesienia przedmiotowego. Dotyczy to również nazw własnych, których użycie nie da się zredukować do wyznaczania odniesienia. Aby to pokazać, posłużmy się przykładem pochodzącym od Fregego (zob. Dummett, 1973, 97):

14 Tak się bowiem charakteryzuje zazwyczaj byt idealny. Uwaga ta dotyczy jednak języka naturalnego. W przypadku języka matematyki stwierdzenie to nie byłoby szokujące, przynajmniej dla niektórych matematyków. 
Frege wyobraża sobie podróżnika penetrującego nieznany region, który dostrzegł na południowym zachodzie szczyt i nazwał go „Alfa”. Około dwudziestu lat później inny podróżnik odkrywa wielki szczyt na północnym zachodzie i nazywa go „Ateb”. Historie obu podróżników stają się znane i obie nazwy szczytów zaczynają być w powszechnym użyciu, ale po pewnym czasie region, w którym znajdują się „Alfa” i „Ateb” zostaje szczegółowo zbadany i opisany i wówczas okazuje się, że był to jeden i ten sam szczyt widoczny z różnych miejsc. [...] Oczywiście po dokonaniu tego odkrycia albo wyeliminuje się jedną z dwóch nazw, albo obie będą używane jako synonimy. Ale zanim dokonano tego odkrycia, stanowi to przykład nazw własnych, używanych w różnych sensach.

Na czym miałoby jednak polegać poznawcza funkcja obu nazw własnych? Nie jest to z pewnością sposób ustalania odniesienia, gdyż nikt z użytkowników języka nie jest w stanie wejść z odniesieniami w bezpośredni kontakt zmysłowy. Poznawcza funkcja nazw własnych polegałoby na zajmowaniu miejsca w całym zespole przekonań na temat szczytów Alfa i Ateb. Byłyby to, jak się okazało, przekonania przynajmniej częściowo fałszywe. Jeżeli jednak utożsamimy funkcję poznawczą nazw z ich sensami, to sensów tych nie da się traktować jako niezależnych od sensów innych wyrażeń występujących w całym zespole przekonań. Skoro jednak znaczenia nie mają być bytami idealnymi, to czym faktycznie są? Dummett twierdzi, że Frege był bliski potraktowania sensu (znaczenia) wyrażenia jako sposobu jego użycia. „Użycie” jest terminem wieloznacznym. W podanym wyżej przykładzie, przez użycie nazwy własnej rozumie się jej występowanie w zdaniach wyrażających pewien zespół przekonań.

W swojej teoria sensu Frege nie rozstrzygnął kwestii znaczenia, ale zainspirował badania tej problematyki we współczesnej filozofii języka.

\section{Kontynuatorzy Fregego}

Odrzucona przez Dummetta interpretacja sensów (znaczeń) jako bytów idealnych została zaadaptowana między innymi przez Alonzo Churcha. Celem teorii znaczenia było, według Churcha, stworzenie abstrakcyjnej teorii faktycznego użycia języka w komunikacji międzyludzkiej, abstrahując od przygodnych lub historycznych danych na ten temat (zob. Church, 1951, 61). Teoria znaczenia miała być teorią normatywną, codzienne zachowanie językowe miałoby zaś spełniać wyznaczone przez tę teorię normy w sposób przybliżony. Normatywność teorii znaczenia oznaczałaby, że teoria ta wyznacza pewien idealny wzorzec, który jest lepiej lub gorzej realizowany w praktyce językowej.

Na czym jednak polegałoby bycie owym wzorcem dla naszych praktyk językowych? Mówienie, podobnie jak mierzenie ziemi, jest działaniem przeprowadzanym według ustalonych reguł. Te same reguły można realizować na wiele sposobów. Geometria nie precyzuje bowiem dokładnie, w jaki sposób należy praktycznie dokonywać pomiarów i jakich przyrządów należy używać, lecz wskazuje jedynie wzorzec, zgodnie z którym pomiary te należy wykonywać. Twierdzenia geometrii stanowią zatem pewne podstawowe reguły, według których musi działać geodeta, aby jego czynność można było nazwać pomiarem ziemi. Geodeta nie musi jednak umieć wy- 
artykułować twierdzeń geometrii. Co więcej, z perspektywy historycznej, to właśnie twierdzenia geometrii zostały w pewien sposób wyabstrahowane z praktycznego działania polegającego na pomiarach ziemi.

Analogicznie do geometrii, teoria znaczenia stanowiłaby zatem wzorzec dla praktycznego działania polegającego na używaniu języka. Reguły podawane przez teorię znaczenia są faktycznie realizowane w praktyce mówienia, gdyż emitowanie dźwięków, które nie realizowałyby tych reguł, nie byłoby używaniem języka. Reguły teorii znaczenia nie są regułami a priori, lecz są wyabstrahowane z naszej praktyki językowej. Oczywiście zarówno w przypadku działania geodety, jak i mówienia, dopuszczalne jest odstępstwo od idealnych reguł. Jednocześnie Church stawia przed teorią znaczenia wysokie wymagania. Powinna ona wyjaśniać wszystkie sposoby używania języka w komunikacji, w tym również trudne do analizy przypadki, jak zdania o wierzeniach, zdania modalne i kontrfaktyczne okresy warunkowe.

Podane wymagania nie precyzują jeszcze, jaką postać powinna przybrać teoria znaczenia. Sam Church przedstawił teorię, która opierała się na regułach przyporządkowujących odniesienia wszystkim wyrażeniom języka i regułach przyporządkowujących znaczenia rozumiane jako obiekty abstrakcyjne, które mogą być interpretowane jako byty idealne. Byłaby to zatem teoria drugiego typu, którą można traktować jako formalizację teorii Fregego. Teoria Churcha kontynuowana była w ramach teoriomodelowej semantyki języka naturalnego, w której rolę znaczenia pełniła tzw. intensja. W dalszej części paragrafu zajmiemy się jednak innymi koncepcjami znaczenia, które - pozostając pod wyraźnym wpływem Fregego ${ }^{15}$ — odegrały ważną rolę w dziejach refleksji nad tym pojęciem.

Weryfikacjonizm, który był doktryną wczesnego neopozytywizmu Koła wiedeńskiego, powstał pod wyraźnym wpływem Traktatu Ludwiga Wittgensteina (zob. Wittgenstein, 1921). W weryfikacjonizmie utożsamiono znaczenie poznawcze zdania z metodą jego weryfikacji16. Istnienie metody weryfikacji zapewnia bowiem bezpośredni i pewny związek między zdaniem a opisywanym fragmentem rzeczywistości. Podobnie jak Arystoteles, weryfikacjoniści stali na gruncie rozumienia prawdy jako ścisłej korespondencji, która zakładała izomorfizm języka i rzeczywistości. Istnienie tego izomorfizmu miało być zapewnione przez istnienie tzw. zdań bazowych (protokolarnych), które miały być bezpośrednio uznawane wobec danych doświadczenia. Wszystkie inne zdania miały być weryfikowane pośrednio, na podstawie zdań bazowych. Okazało się jednak, że — nawet w przypadku języka fizyki — redukcja zdań do zdań bazowych okazała się niemożliwa, co sprawiło, że weryfikacjonizm został przez neopozytywistów praktycznie zarzucony, najczęściej na rzecz behawioryzmu.

Behawioryzm opierał poznawczą funkcję języka na bezpośrednim kojarzeniu bodźców werbalnych (zastępczych) i bodźców bezpośrednich, odwołując się początkowo do zasady uwarunkowania, później zaś do zasady wzmocnienia. Typowym przykładem dojrzałej behawiorystycznej teorii znaczenia, i to teorii po raz pierwszy stworzonej dla języka naturalnego, jest teoria znaczenia W. V. O. Quine'a przedstawiona w Word and Object (zob. Quine, 1960). Teoria ta opiera się pojęciu przekładu,

15 Brak tu miejsca na przeanalizowanie związków między tymi teoriami a teorią sensu Fregego. Czynię to w Maciaszek (2008).

16 Zasada weryfikacji prowadziła do stwierdzenia, że zdania, dla których nie istnieje metoda weryfikacji empirycznej są bezsensami pozbawionymi znaczenia. Nie trzeba nikogo przekonywać, że przeważająca część naszych wypowiedzeń kwalifikowałoby się do owych bezsensów. 
a dokładniej podręcznika przekładu. W myśl tej teorii podać znaczenia wyrażeń jakiegoś języka, to nic innego, jak przełożyć ten język na język już znany, za pomocą podręcznika podającego przekłady zdań z jednego języka na drugi. Byłby to zatem przykład teorii trzeciego typu, w której nie występuje explicite termin „znaczenie”. ${ }^{17}$ Używa się go jedynie w metajęzyku tej teorii, np. w komentarzach na jej temat. Teoria Quine'a ma charakter teorii holistycznej, gdyż podręcznik przekładu podaje znaczenia poszczególnych wyrażeń jedynie w kontekście całego języka. Uwarunkowaniom i genezie holizmu znaczeniowego poświęcony zostanie następny paragraf.

\section{W stronę holistycznych teorii znaczenia}

Jednym z czynników, który przyczynił się do odrzucenia trywialnych teorii znaczenia oraz weryfikacjonizmu, był wzrost zainteresowania językiem naturalnym. Teorie te nie mogły być traktowane jako teorie znaczenia języka naturalnego, lecz co najwyżej pewnej jego części, która po odpowiednim uściśleniu mogła pełnić funkcję języka teorii naukowej. Były one oparte na założeniu zachodzeniu ścisłej korespondencji między językiem a rzeczywistością. Okazało się jednak, że zasada ścisłej korespondencji została zakwestionowana nawet w przypadku języków teorii naukowej. Stało się to na przełomie lat czterdziestych i pięćdziesiątych XX wieku za sprawą Quine’a oraz Hempla, którzy rozpropagowali tezę holizmu konfirmacyjnego. Teza ta, która powstała znacznie wcześniej na gruncie konwencjonalizmu i związana jest z filozofią nauki, wywarła znaczący wpływ na teorie znaczenia, gdyż przyczyniła się do odrzucenia znaczeń jako bytów, które zapewniają wzajemnie jednoznaczną zależność między zdaniami i „układami rzeczy”. Tę samą rzeczywistość można opisywać na wiele sposobów, przy czym każdy język opisu jest trafny, o ile jest zgodny z ogółem danych doświadczenia. Holizm konfirmacyjny postawił przed teorią znaczenia nowe zadanie, które musiały wyjaśnić wielość możliwych opisów świata.

Konwencjonalizm był nurtem w filozofii nauki, który powstał we Francji na przełomie XIX i XX wieku. Twórcą konwencjonalizmu był Henri Poincaré. Tradycyjny konwencjonalizm dotyczył przede wszystkim teorii naukowych, np. systemów aksjomatycznych. Wybór konkretnej aksjomatyki, np. geometrii euklidesowej lub geometrii nieuklidesowej czy logiki klasycznej lub logiki kwantowej, pozwala na sformułowanie różnych teorii fizycznych opisujących te same dane doświadczenia. ${ }^{18}$ Według tradycyjnych konwencjonalistów w takich przypadkach uczeni dokonują wyboru teorii zgodnie z pewną konwencją. W wyborze konwencji kierują się pewnymi względami „pobocznymi”, np. prostotą, naukową użytecznością, intuicyjnością itp. Zdaniem konwencjonalistów żadna z konkurencyjnych teorii fizycznych, o ile jest zgodna z dostępnymi danymi doświadczenia, nie stanowi wierniejszej reprezentacji rzeczywistości. Każda teoria jest równie prawdziwa. Mamy zatem do czynienia ze

17 Sprawę pozornie komplikuje fakt wprowadzenia przez Quine’a tzw. znaczeń bodźcowych. Znaczenia bodźcowe nie mogą jednak być utożsamiane ze znaczeniami językowymi w jakimkolwiek interesującym nas sensie.

18 Okazuje się bowiem, że pewne teorie fizyki współczesnej formułowane są w znacznie prostszy sposób, gdy odrzuci się geometrię euklidesową na rzecz jakiejś geometrii nieeuklidesowej lub klasyczną logikę dwuwartościową na rzecz logiki kwantowej. Zasadniczo można obstawać przy geometrii Euklidesa lub logice klasycznej - wiąże się to jednak ze znaczną komplikacją teorii. 
zdecydowanym odejściem od rozumienia prawdy jako ścisłej korespondencji. Opisy lub obrazy świata dostarczane przez konkurencyjne teorie nie są zatem wzajemnie jednoznacznymi odwzorowaniami rzeczywistości. Każdy opis uzupełniony jest konwencjami, pewnymi arbitralnie przyjętymi założeniami, które ów obraz świata współtworzą i dzięki którym nasz obraz świata jest w miarę prosty i spójny.

Umiarkowani konwencjonaliści uważali, że opis zjawisk za pomocą języka naturalnego nie zawiera elementów konwencji. Stanowisko umiarkowanego konwencjonalizmu reprezentował również Pierre Duhem, który w doświadczeniu wyróżnił dwa składniki: obserwację i interpretację. Obserwacja polega na zmysłowym percypowaniu zjawisk i jest dostępna dla każdego. Drugi składnik, dostępny jedynie dla osób, które znają odpowiednie teorie, Duhem nazywa interpretacją. Interpretacja jest to opis danych doświadczenia, ale w języku pewnej teorii. Konwencjonaliści umiarkowani uznawali, że owe opisy danych doświadczenia za pomocą terminów języka naturalnego, zwane niekiedy zdaniami sprawozdawczymi, są jednoznacznymi opisami rzeczywistości. Z kolei tzw. zdania interpretacyjne pojawiają się dopiero na poziomie języka teorii naukowej. Zdania sprawozdawcze miały bezpośrednio opisywać dane doświadczenia bez jakichkolwiek konwencji; zdania interpretacyjne opisywały rzeczywistość, lecz przez pryzmat konwencji przyjętych wraz z teoriami naukowymi.

Pozostając pod wpływek konwencjonalizmu, Ajdukiewicz zakwestionował rozróżnienie między zdaniami sprawozdawczymi a interpretacyjnymi. Jedyna różnica między tymi zdaniami polega na tym, że uznając zdania interpretacyjne, odwołujemy się do świadomie przyjętych konwencji; uznając zdania sprawozdawcze, odwołujemy się również do konwencji, lecz przyjętych nieświadomie. Konwencje te są w pewien sposób ugruntowane w języku naturalnym, w wyuczonych przez nas zwyczajach językowych. W artykule Jezyk i znaczenie Ajdukiewicz utożsamił konwencje z tzw. dyrektywami znaczeniowymi ${ }^{19}$ (zob. Ajdukiewicz, 1960, 145-174), które można w przybliżeniu określić jako opisy dyspozycji do aktów uznawania zdań. Od przyjmowania konwencji językowych nie można się w żaden sposób uwolnić. „Naukowy” obraz świata wybitnego fizyka i „naiwny” obraz świata zwykłego człowieka jest w równym stopniu kształtowany przez konwencje:

Jedyna różnica pomiędzy zdaniami sprawozdawczymi a interpretacyjnymi polega więc na tym, że pierwsze są rozstrzygalne w językach, w których wyrośliśmy, stworzonych bez naszego świadomego udziału, gdy drugie mogą być rozstrzygnięte dopiero w takich językach, przy których budowie braliśmy świadomie udział (Ajdukiewicz, 1960, 186).

Nie ma zatem neutralnych i wolnych od konwencji opisów świata. Teoria znaczenia ma wyjaśnić poznawczą funkcję języka, rozumianą jednak nie jak dotychczas biernie, lecz czynnie. Współtworzenie obrazu świata przez język zakłada, że współtworzony przez język obraz świata stanowi pewną całość. Wyrazem poglądów

19 Dyrektywy znaczeniowe, których nie będę tu bliżej charakteryzował, dzielą się na aksjomatyczne, dedukcyjne i empiryczne. Podział ten motywowany jest różną mocą uznawanych zdań. Zdania mogą być wypowiadane z mocą twierdzenia, mogą być wnioskowane z innych zdań lub stwierdzane wobec pewnych danych doświadczenia. 
konwencjonalistycznych jest teza holizmu konfirmacyjnego, która po raz pierwszy została sformułowana przez Duhema. ${ }^{20}$ Cytuję za Szlachcic (1991):

Reasumując, fizyk nie może nigdy poddać kontroli doświadczenia pojedynczej hipotezy, lecz tylko całą grupę hipotez. Kiedy doświadczenie nie zgadza się z jego przewidywaniami, wskazuje mu to, że przynajmniej jedna z hipotez tworzących tę grupę jest błędna i musi być zmieniona, lecz nie wskazuje mu tej, która powinna być poprawiona. (...) Nauka fizyczna jest organizmem, w którym nie można uruchomić żadnej części nie poruszając innych, choćby najbardziej odległych od niej; poruszyć, jedne bardziej, drugie słabiej, ale wszystkie w jakimś stopniu wprawić w ruch.

Teza głosi, że nie można potwierdzić lub sfalsyfikować empirycznie pojedynczego zdania teorii. Jest ona rezultatem przekonania, że każda hipoteza jest rezultatem pewnej interpretacji dostępnych danych doświadczenia, tworząc z pozostałymi zdaniami teorii „organiczną całośc”, która stanowi o obrazie świata dostarczonym przez daną teorię.

Nieco wcześniej była mowa o tym, że teoria znaczenia powinna wyjaśniać to, że język, w tym przypadku język teorii naukowej, współtworzy pewien (językowy) obraz świata, który odpowiada dyspozycjom do werbalnego aktualizowania przekonań na temat świata, która przejawia się odpowiednim użyciem zdań w danym języku. W świetle tezy Duhema teoria znaczenia powinna wyjaśniać związki między zdaniami danej teorii. Związki te polegają na tym, że odrzucenie pewnego zdania danej teorii wobec nowych danych doświadczenia wymaga odrzucenia całej grupy uznawanych do tej pory zdań i uznania całej grupy zdań, które do tej pory nie były uznawane. Tak rozumiane związki między zdaniami teorii mogą być wyjaśnione przez odwołanie się do związków znaczeniowych między wyrażeniami wchodzącymi w skład języka teorii.

Niewątpliwym wkładem Ajdukiewicza do filozofii języka było przeniesienie poglądów konwencjonalistycznych na płaszczyznę językową i sformułowanie holistycznej teorii znaczenia, która uwzględniała związki znaczeniowe między wyrażeniami w języku teorii naukowej. Co więcej, teoria Ajdukiewicza, chociaż sformułowana dla języków teorii naukowych, rzuca wiele światła na problemy związane z użyciem języka naturalnego. Znaczenie wyrażenia można określić jako miejsce tego wyrażenia w (holistycznym) układzie przekonań ${ }^{21}$. Określenie to, chociaż wydaje się nieco abstrakcyjne, nie jest niezgodne z naszymi intuicjami. Aby znać jakikolwiek język, należy faktycznie żywić szereg przekonań i umieć je aktualizować za pomocą zdań tego języka. Jeśli ktoś nie uznaje zdania „To jest pies” w obecności typowego przedstawiciela tego gatunku lub nie uznaje zdania „Dwa i dwa to cztery”, to nie powiemy, że jest słaby z zoologii lub arytmetyki, lecz że nie zna języka polskiego.

Posługiwanie się językiem zakłada żywienie przekonań wyrażalnych w tym języku, czyli pewną wiedzę. Aktualizowanie owej wiedzy Ajdukiewicz określał jako uży-

20 Obecnie znana jako teza Duhema-Quine'a.

21 Ajdukiewicz był zwolennikiem tezy holizmu konfirmacyjnego, holizmu przekonaniowego oraz holizmu znaczeniowego. 
cie języka. W tym sensie Ajdukiewicz antycypował poglądy Ludwiga Wittgensteina z Dociekań filozoficznych.

\section{Znaczenie jako użycie u późnego Wittgensteina}

Wittgenstein znany jest przede wszystkim jako autor niezwykle znanego frazesu, że znaczenie wyrażenia jest jego użyciem — pojawiło się ono w Dociekaniach filozoficznych (zob. Wittgenstein, 1953) Nie należy jednak traktować poglądów Wittgensteina jako udanej próby stworzenia nowej teorii znaczenia - jak słusznie zauważył Bogusław Wolniewicz we wstępie do Dociekań:

O tym, że dwa słowa znaczą to samo, ma decydować tożsamość ich użycia. Bardzo dobrze, ale jak ją rozpoznać? Tę krytyczną kwestię zostawia się w Dociekaniach w zupełnej nieokreśloności (zob. Wittgenstein, 2000 (1953), XXIV).

Jest to niezwykle istotna kwestia, gdyż jeżeli znaczenie terminu „użycie” potraktujemy szeroko, jak faktycznie uczynił to Wittgenstein, uniemożliwi to zbudowanie jakiejkolwiek teorii znaczenia. Budując teorię znaczenia, musimy zatem sprecyzować, o jakie rozumienie tego terminu nam chodzi. Podobnie jak wcześniej Frege, Wittgenstein wskazuje na kierunek, w jakim należy się posuwać, pragnąc zbudować teorię znaczenia. Dociekania stanowią raczej listę pytań i wątpliwości, niż rozwiązań. W porównaniu do Traktatu (zob. Wittgenstein, 1921), następuje całkowita zmiana sposobu widzenia roli języka. W Traktacie doskonały język miał idealnie odwzorowywać strukturę logiczną świata. W Dociekaniach język naturalny służy do działania, jest używany w grach, które toczymy z otoczeniem i innymi ludźmi. W Traktacie Wittgenstein stał na gruncie teorii prawdy jako ścisłej korespondencji, która zakłada izomorficzność struktur rzeczywistości i struktur językowych. W Dociekaniach pojęcie prawdy staje się pojęciem całkowicie pragmatycznym:

Czym jest zdanie, to w pewnym sensie określają reguły budowy zdań (np. języka polskiego), a w innym - użycie znaków w grze językowej. Składnikiem tej gry może być również użycie słów „prawda” i „fałsz” (zob. Wittgenstein, 2000 (1953), 80).

Przytoczone tu stwierdzenie nie musi być interpretowane zbyt radykalnie. Da się ono pogodzić z rozumieniem prawdy jako korespondencji między językiem a rzeczywistością - nie będzie to jednak ścisła korespondencja jak u Arystotelesa lub w Traktacie 22 .

Funkcji opisowej, która dominowała do tej pory w teoriach znaczenia, przeciwstawia Wittgenstein szeroko rozumianą funkcję „użyciową” — wyrażenia języka są używane w komunikacji językowej, która wykracza poza przekazywanie symbolicznego obrazu rzeczywistości. Komunikując się za pomocą języka, osiągamy różne cele. W szczególności możemy opisać rzeczywistość, skłonić kogoś do działania, obiecać

22 Dokładniejsze rozważania na temat prawdy jako korespondencji, która umożliwia wielość opisów tej samej rzeczywistości, przeprowadzam w Maciaszek (2008, 383-408). 
coś, zapytać o coś itp. O tym, w jaki sposób użyliśmy danego wyrażenia, decyduje kontekst użycia ${ }^{23}$. Każdy akt wypowiedzenia zdania ma miejsce w ramach większej całości, którą Wittgenstein nazywa metaforycznie grą językową.

$\mathrm{Na}$ naszą komunikację językową składają się zatem gry, które mniej lub więcej świadomie prowadzimy z naszymi interlokutorami, czytelnikami lub sami z sobą. Każda gra ma swoje reguły — rozkazy, twierdzenia lub odpowiedzi są odpowiednikami ruchów w grze. Wyrażenie językowe nabiera znaczenia dopiero w kontekście całej gry — poglądy Wittgensteina mają zatem wyraźnie holistyczne zabarwienie. Dźwięk równokształtny z wypowiedzianym zdaniem sam w sobie zdaniem nie jest, o ile nie został on faktycznie użyty. Myśl tę Wittgenstein ujął w słynnej metaforze:

Sam przez się każdy znak zdaje się martwy. Co nadaje mu życie? - Żyje on w użyciu. Czy ma wówczas w sobie tchnienie życia? A może tym tchnieniem jest użycie? (zob. Wittgenstein, 2000 (1953), 182).

Użycie znaku, a właściwie użycie jego kształtu fizycznego w kontekście zwanym grą językową, „ożywia go”, tj. nadaje mu znaczenie.

Wittgenstein traktuje ruchy w grach językowych jako takie same czynności ludzkie, jak wszelkie działania pozajęzykowe, wszelkie czynności wykonuje się zaś za pomocą narzędzi. Samo w sobie narzędzie jest jedynie martwym przedmiotem - o tym, że staje narzędziem decyduje to, w jaki sposób jest ono używane. Każdy przedmiot może być używany do wielu celów, pełniąc funkcje wielu narzędzi, chociaż jedna $\mathrm{z}$ nich jest zazwyczaj funkcją zasadniczą lub standardową. Podobnie jest z wyrażeniami językowymi. Kształt fizyczny — dźwięk lub napis — staje się wyrażeniem języka w ramach prowadzonej gry językowej. Jak wiadomo, użycie wyrażeń może mieć charakter dosłowny i niedosłowny. Każdy z nas może bowiem wymyślać nowe, „niedosłowne" posunięcia w grze językowej. Oficer, który mówi oficjalnie do żołnierza „Proszę biec do tamtego drzewa”, z całą pewnością nie prosi o nic, lecz w ironiczny sposób rozkazuje.

Prowadzi to do bardzo poważnego problemu, którego Wittgenstein w Dociekaniach nie rozwiązuje, gdyż nie definiuje precyzyjnie pojęcia gry językowej. Wyrażenia są używane w grach językowych, których reguły często sami modyfikujemy, używając wyrażeń w sposób niedosłowny. Tworzymy zdania metaforyczne, aluzyjne i ironiczne. Wtrącenie takiego zdania do gry językowej jest jakby dołączeniem do znanej gry, opartej na znanych regułach, nowego ruchu, ruchu, którego reguły tej gry nie przewidują. Problem niedosłowności stanowi spore wyzwanie dla teorii znaczenia opartej na użyciu. Jak bowiem przy tak szerokim rozumieniu terminu „użycie” odróżnić użycie dosłowne od niedosłownego? Teoria znaczenia powinna uporać się również z tym problemem.

Wittgenstein utożsamia znajomość języka z dyspozycją do prowadzenia mnogości gier językowych, od których reguł możemy odstępować, używając wyrażeń w sposób niestandardowy, czyli niedosłowny. Jakie sposoby użycia wyrażeń składają się zatem na ich znaczenia? Czy każde wyrażenie może mieć potencjalnie nieskończenie wiele znaczeń lub odcieni znaczeniowych, zrelatywizowanych do różnych gier językowych, które

23 Dlatego też Wittgenstein traktowany jest jako prekursor pragmatyki rozumianej jako badanie użycia wyrażeń w kontekście. Inne rozumienie pragmatyki - jako badanie konsekwencji użycia wyrażeń — pojawia się u Donalda Davidsona. 
możemy w języku prowadzić? Wittgenstein nie łączy jednak znaczeń z poszczególnymi grami językowymi, lecz z całym językiem (zob. Wittgenstein, 2000 (1953), 34).

$\mathrm{Na}$ początku rozdziału wspomniałem, że teoria znaczenia powinna wyjaśnić, na czym polega rozumienie wyrażeń, a dokładniej — podawać warunek możliwości rozumienia języka. Sporą część Dociekań Wittgenstein poświęca pokazaniu, że pojęcie rozumienia jest w pewnym sensie nieuchwytne i nie możemy powiedzieć o rozumieniu wyrażeń niczego innego, jak to, że jest ono reprezentowane przez użycie. Rozumienie jest jedynie aktem psychicznym, który aktualizuje dyspozycje językowe do użycia wyrażeń. O tym, że ktoś rozumie wyrażenia, tj. zna ich znaczenia, poznajemy to po jego zachowaniu językowym oraz po zachowaniu, które mu towarzyszy.

Refleksje nad znaczeniem późnego Wittgensteina trudno określić mianem teorii znaczenia. Byłaby to bardzo metaforycznie sformułowana teoria użycia. Na uwagę zasługuje jednak włączenie do zakresu problematyki znaczenia zdań performatywnych, czyli wyjście poza utożsamianie znaczenia z sensem.

\section{Kształt teorii znaczenia według Michaela Dummetta}

Teorie znaczenia Quine’a, Ajdukiewicza oraz Wittgensteina nie operują explicite terminem „znaczenie”. Termin ten jest używany jedynie w metajęzyku owych teorii. Są to faktycznie teorie przekładu, układów przekonań oraz użycia wyrażeń językowych. W tym paragrafie przedstawię dyskusję, jaką na temat teorii znaczenia przeprowadził Michael Dummett. Dyskusja ta ogniskuje się na pytaniu, czy teoria znaczenia musi w ogóle posługiwać się tym terminem.

Porównując problematykę znaczenia z epistemologią, czyli teorią wiedzy, Dummett zwraca uwagę na to, że pomimo tego, że przednaukowe odpowiedniki podstawowych pojęć epistemologii są niejasne, to nie ulega wątpliwości, jaką postać powinny przybrać zdania teorii, która owe pojęcia uściśla (zob. Dummett, 1993, 1). Zupełnie inaczej jest w przypadku teorii znaczenia. To, że przednaukowe pojęcie znaczenia jest niejasne, nie wyróżnia jeszcze teorii znaczenia spośród innych teorii, gdyż teorie naukowe buduje się, aby uściślać pojęcia. W przypadku teorii znaczenia nie jest jednak jasne nawet to, czy należy analizować zdania, które bezpośrednio przypisują znaczenia wyrażeniom języka, np. „A znaczy $B$ ” lub „A znaczy, że $B$ ”. Być może, zastanawia się Dummett, nie można w ogólnym przypadku przypisywać znaczeń wyrażeniom, jak czynią to wymienione zdania, lecz być może powinniśmy zbadać, za pomocą jakich środków językowych lub pozajęzykowych można podawać znaczenia wyrażeń, nie przypisując im konkretnych bytów jako znaczeń. Teoria taka powinna zatem wyjaśnić w jakiś inny sposób, co to jest znaczenie i w pewien sposób podać znaczenia dla wszystkich słów i zdań języka. Ponieważ w każdym języku można formułować nieskończenie wiele zdań, teoria znaczenia powinna mieć charakter rekurencyjny, gdyż powinna uwzględniać zachodzenie w języku zasady składalności znaczeń, dzięki której znaczenia potencjalnie nieskończonej liczby wyrażeń złożonych i zdań mogą być wyznaczone przez znaczenia skończonej liczby wyrazów i operacji zdaniotwórczych.

Kolejny intuicyjny postulat Dummetta dotyczy pojęcia rozumienia, które tradycyjnie utożsamiane było z „chwytaniem” znaczenia. Według Dummetta „uchwycić znaczenie” wyrażenia to zrozumieć rolę wyrażenia w języku (zob. Dummett, 1993, 
2). W stwierdzeniu tym wyraźnie pobrzmiewa postulat Wittgensteina z Dociekań, aby teoria znaczenia była teorią użycia języka. ${ }^{24}$

Z rekurencyjnością języka wiąże się wymóg wyuczalności. Teoria znaczenia powinna podawać zatem opis funkcjonowania języka wraz z opisem „[...] tego wszystkiego, czego należy nauczyć się robić, aby nauczyć się języka” oraz „[...] móc wskazać na to, co należy wiedzieć, aby znać język” (zob. Dummett, 1993, 2). Uczenie się języka jest tożsame z nabywaniem dyspozycji do pewnych zachowań, znajomość języka jest zaś tożsama z posiadaniem ogółu owych dyspozycji. Teorię znaczenia danego języka Dummett traktuje zatem jako opis wyuczonych dyspozycji do działań za pomocą zdań tego języka. Znajomość języka łączy zatem z pewną szeroko rozumianą wiedzą językową, z której powinna zdać sobie sprawę teoria znaczenia. ${ }^{25}$

Na rzecz powiązania wiedzy z rozumieniem języka można podać dwa argumenty. Pierwszy z nich dotyczy sposobu uczenia się języka - uczenie się języka, czyli proces dochodzenia do rozumienia wyrażeń danego języka, jest procesem, któremu nieodłącznie towarzyszy proces zdobywania wiedzy w szerokim sensie. Również proces zdobywania wiedzy naukowej ma charakter zwerbalizowany i stanowi faktycznie proces uczenia się nowego języka. Nawet jeśli fizyczne kształty słów nie są nowe, to uczymy się używać owych słów w nowy sposób, tj. nadajemy im nowe znaczenia.

Warunkiem wyuczalności języka, którą postuluje Dummett, jest również możliwość zrozumienia wyrażeń prostych tego języka. Prowadzi to Dummetta do kolejnego wymogu: teoria znaczenia powinna obejmować wyjaśnienie wszystkich pojęć wyrażalnych w tym języku:

Jeżeli teoria znaczenia pewnego języka podaje wyjaśnienie funkcjonowania tego języka, to musi obejmować wyjaśnienie wszystkich możliwych pojęć wyrażanych w tym języku, przynajmniej zaś pojęć jednostkowych (zob. Dummett, 1993, 4).

Pomijając niezwykle niejednoznaczny termin „pojęcie”, wymóg ten sprowadza się do tego, aby teoria znaczenia wyjaśniała, w jaki sposób możliwe jest rozumienie wyrażeń prostych (słów). Część wyrażeń prostych można wyjaśnić poprzez tzw. ostensję lub definicje odwołujące się do słów już znanych. Nie może to jednak dotyczyć wszystkich wyrażeń, gdyż ich znaczenie poznajemy w kontekście zdań.

W monografii na temat Fregego Dummett wyróżnił dwie drogi dochodzenia do znaczeń. Wspomniana już zasada składalności sensów, związana z wymogiem rekurencyjności teorii znaczenia, przynależy do tzw. porządku rozpoznawania sensów. W porządku rozpoznawania sensów pierwszeństwo ma sens wyrazu. Użytkownik języka jest w stanie zrozumieć zdanie, tj. uchwycić sens zdania znanego mu języka, poprzez uprzednie rozpoznanie sensów występujących w nim słów (zob. Dummett, 1973, 4). Od porządku rozpoznawania sensów Dummett odróżnił porządek wyjaśniania sensów. Aby wyjaśnić znaczenie wyrazu lub, innymi słowy, przypisać wyrazo-

24 Wpływ myśli Wittgensteina na Dummetta jest oczywisty. Przejawia się on również w „życiowej” interpretacji teorii sensu Fregego w Dummett, 1973.

25 W tym miejscu warto przypomnieć, na co zwrócił uwagę w swojej teorii Ajdukiewicz, że warunkiem znajomości języka jest posiadanie pewnej wiedzy. W przypadku języka naturalnego jest to wiedza potoczna na temat otaczającej rzeczywistości. Bez tej wiedzy nie jest możliwe użycie języka w jakimkolwiek sensie terminu „użycie”. 
wi pewne znaczenie, należy odwołać się do „sposobu, w jaki może być on użyty do budowy zdań” (zob. Dummett, 1993, 4).

Wyjaśnienie przez teorię znaczenia, w jaki sposób realizowany jest w języku porządek wyjaśniania, pozwala ją zakwalifikować do tzw. teorii pełnokrwistych. Teoria taka „[...] powinna służyć do wyjaśnienia nowych pojęć osobie, która ich jeszcze nie posiada" (zob. Dummett, 1993, 4). W odróżnieniu od teorii pełnokrwistej, tzw. teoria umiarkowana spełnia słabszy warunek. Musi ona jedynie przypisać słowom języka pojęcia, które są już w ten czy inny sposób znane, np. w jego własnym idiolekcie.

Typowym przykładem umiarkowanej teorii znaczenia jest, zdaniem Dummetta, teoria znaczenia Quine’a, wyrażona w kategoriach podręcznika przekładu, gdyż ten podaje tłumaczenia zdań obcego języka na język ojczysty. Pozwala to przypisać słowom obcego języka znane pojęcia, które potrafimy wyrazić za pomocą słów naszego języka. Teoria ta jednak nie pozwala wyjaśnić, na czym polega dochodzenie do pojęć wyrażanych we własnym języku, ani nie pozwala wyjaśnić pojęć języka obcego, które nie mają odpowiedników w języku nam znanym. Wprowadzone tu pojęcia stanowiły pretekst do znanej polemiki między Dummettem a Davidsonem.

\section{Teoria interpretacji Donalda Davidsona}

W pierwszym artykule poświęconym filozofii języka Davidson formułuje podstawowe kryterium, które powinna spełniać poprawna teoria języka naturalnego, czyli teoria, którą utożsamia z teorią znaczenia języka naturalnego (zob. Davidson, 1966). Taka teoria powinna przede wszystkim uwzględniać fakt wyuczalności języka. Davidson nie wymaga, aby teoria znaczenia wyjaśniała „mechanizm” uczenia się języka, lecz uwzględniała warunki możliwości wyuczalności języka. Teoria znaczenia ma być zatem teorią logiczną, czy raczej filozoficzną. Znajomość języka jest to pewna dyspozycja, którą nabywamy w ograniczonym w czasie procesie uczenia się języka. Bez względu na to, jak przebiega ów proces, celem teorii znaczenia jest wyjaśnienie możliwości tego procesu.

Sama teoria znaczenia nie pozwoli nam stwierdzić, co mówiący faktycznie rozumie przez określone zdanie swojego języka. Teoria ta powinna jednak pomóc nam w tym, jeśli przypiszemy mu stany psychiczne 26 :

Mając do dyspozycji odpowiednie świadectwa dotyczące stanów psychicznych, teoria pozwoli nam orzec, co mówiący rozumie przez dowolne zdanie. Dysponując adekwatną teorią widzimy, w jaki sposób działania i dyspozycje mówiących, odciskają na zdaniach języka strukturę semantyczną (Davidson, 2001a (1966), 8).

Aby stosować teorię znaczenia, tj. przypisać w ten czy inny sposób znaczenia czyimś słowom, należy poza samą teorią dysponować odpowiednimi świadectwami, np. danymi doświadczenia (bodźcami) i zachowaniami innych ludzi, które, wraz z wypowiedzianymi przez nich słowami, pozwalają na przypisanie im postaw propozy-

26 Problematyce przypisywania postaw propozycjonalnych poświęcone są artykuły zebrane w Davidson, $2001 b$. 
cjonalnych. Dlatego też teoria znaczenia stanowi część tzw. teorii interpretacji, którą można traktować jako niezwykle subtelną filozofię człowieka.

Wyjaśnianie faktu wyuczalności języka przez znane teorie znaczenia nie jest bynajmniej oczywiste i trywialne. Pokazał to Davidson, krytykując kilka wybranych teorii znaczenia, między innymi wspomnianą teorię Churcha (zob. Davidson, 2001a (1966), 9-15). ${ }^{27}$ Istota tej krytyki polega na pokazaniu, że żadna istota o skończonych możliwościach nie jest w stanie w skończonym czasie nauczyć się systemów znaków, opisywanych przez te teorie. Innymi słowy, krytykowane teorie nie są teoriami znaczenia żadnego języka, bo język musi być wyuczalny. ${ }^{28}$

Teoria języka wyuczalnego musi, zdaniem Davidsona, dokonać redukcji przedteoretycznego predykatu dyspozycyjnego „wyuczalny” do innego predykatu opisującego cechę składalności, zwanej również kompozycjonalnością. Adekwatna, czyli kompozycjonalna teoria języka wyuczalnego musi bowiem podawać jego konstruktywny, czyli rekurencyjny opis:

Proponuję coś, co wydaje mi się w sposób oczywisty konieczną cechą wyuczalnego języka: musi być możliwe podanie konstruktywnego opisu znaczenia zdań tego języka. Opis ten nazywam teorią znaczenia (Davidson, 2001a (1966), 3)

Wymóg kompozycjonalności języka pojawił się, jak pamiętamy, już u Fregego. Wiązał się z wprowadzeniem rozróżnienia na funktor i jego argument. Kompozycjonalność języka przejawiała się u Fregego obowiązywaniem zasady składalności odniesień i zasady składalności sensów ${ }^{29}$. Davidson rozumie jednak kompozycjonalność w inny sposób niż Frege. Przede wszystkim, jak pokaże to w artykule Prawda $i$ znaczenie (zob. Davison, 1967) oraz w szeregu późniejszych artykułów, kompozycjonalność w sensie Fregego ani nie zapewnia, ani nie wyjaśnia wyuczalności języka. Nie każda teoria rekurencyjna może być zatem teorią języka wyuczanego. Teoria taka, w odróżnieniu od teorii Fregego oraz teorii krytykowanych w Teoriach znaczenia, które są niewątpliwie rekurencyjne w sensie matematycznym, musi odwoływać do skończonej liczby wyrażeń semantycznie pierwotnych. Doprowadziło to Davidsona to stworzenia semantyki, która nie operuje pojęciem odniesienia, zbudowanej w oparciu o teorię prawdy Tarskiego ${ }^{30}$.

Teoria Tarskiego została stworzona dla języków formalnych. Język formalny jest opisywany za pomocą zazwyczaj bardzo prostych, rekurencyjnych reguł składni ustalonych arbitralnie przez twórcę tego języka oraz równie prostych reguł semantycz-

27 Davidson krytykuje kolejno różne wersje teorii znaczenia wyrażeń cudzysłowowych oraz znaczenia zdań w mowie zależnej, w szczególności zdań o wierzeniach. Problemy te rozwiązywał w późniejszych publikacjach, zebranych w Davidson, 2001a.

28 Wyjaśnienie wyuczalności prowadzi nas do nieco wcześniejszego wystąpienia Chomsky’ego. W słynnej recenzji książki Skinnera Verbal behavior (Chomsky, 1959) zwrócił uwagę na to, że behawiorystyczny opis posługiwania się językiem, który odwołuje się do pojęcia wzmocnienia, nie jest w stanie wyjaśnić produktywności języka.

29 Zachodzenie obu zasad w semantyce Fregego było możliwe dzięki wprowadzeniu rozróżnienia na tzw. wyrażenia nienasycone i nasycone. Odniesieniem wyrażenia nienasyconego była funkcja, nienasyconego zaś jej argument.

30 Teoria lub definicja prawdy Tarskiego (zob. Tarski, 1933) stanowi przedmiot licznych kontrowersji. Sam Davidson posługiwał się określeniem „teoria w stylu definicji prawdy Tarskiego” i nadał tej teorii swoistą interpretację. 
nych. W przypadku języków naturalnych sytuacja jest zupełnie inna, postulat sformułowania teorii znaczenia dla całego języka naturalnego jest, z czego sobie Davidson zdawał sprawę, nierealistyczny. Pomysł Davidsona polega w istocie na tym, aby nie budować teorii znaczenia przez „sklejanie” jej z różnych kawałków, lecz, aby stworzyć teoretyczne ramy - miała nimi być teoria prawdy - pozwalające na opis w ramach tej samej teorii coraz to większych fragmentów języka naturalnego. Adekwatna teoria znaczenia powinna wzorować się na teorii prawdy Tarskiego, uwzględniając specyfikę języka naturalnego, np. jego okazjonalność. Jest to zapowiedź programu semantycznego, który realizował przez całe życie. ${ }^{31}$

Teoria prawdy, adaptowana przez Davidsona, faktycznie pełni tę samą rolę co podręcznik przekładu u Quine’a. Pozwala ona bowiem przełożyć wypowiedzenia drugiego człowieka na idiolekt interpretatora. W przeciwieństwie do teorii podręcznika przekładu charakteryzuje się ona rekurencyjnością. Aby przyjrzeć się chociaż pobieżnie temu, jak funkcjonuje teoria prawdy w stylu Tarskiego, jako teoria znaczenia $\mathrm{w}$ ramach teorii interpretacji, rozpatrzmy następujący przykład.

Wyobraźmy sobie, że nasz znajomy Jaś, znany z notorycznego mylenia pojęć, wypowiada o innym znajomym — Piotrze, o którym wiemy, że jest z wykształcenia filologiem, zdanie: „Piotr jest filozofem”. Interpretacja tej wypowiedzi zależy od kontekstu wypowiedzenia, naszej wiedzy na temat Jasia, wiedzy na temat Piotra oraz przypuszczeń co do tego, co Jaś wie o Piotrze. Niebagatelną rolę pełnią również nasze dotychczasowe próby zinterpretowania różnych wypowiedzi Jasia. Możliwości zinterpretowania tej wypowiedzi jest teoretycznie nieskończenie wiele, w sposób naturalny nasuwają się trzy możliwości.

I. Uznajemy, że Jaś jest przekonany o Piotrze, że jest filologiem, lecz rozumie słowo „filozof”, tak jak my słowo „filolog”. Nasza szczątkowa teoria prawdy przybrałaby podaną niżej postać 32 :

1. Każdy nieskończony ciąg C przyporządkowuje stałej „Piotr” obiekt zwany w naszym idiolekcie Piotrem, czyli po prostu Piotra.

2. Zdanie „a jest filozofem” jest spełnione przez ciąg $C$ wtedy i tylko wtedy, gdy obiekt przyporządkowany stałej $a$ przez $C$ jest filologiem.

3. Zdanie $Z$ idiolektu Jasia jest prawdziwe wtedy i tylko wtedy, gdy jest spełnione przez wszystkie ciągi.

Zauważmy, że nasz własny idiolekt pełni tu rolę metajęzyka, w którym buduje się teorię prawdy dla idiolektu Jasia. Z podanych wyżej reguł semantycznych (1) i (2) oraz definicji prawdy wynika tzw. T-zdanie:

4. Zdanie (Jasia) „Piotr jest filozofem” jest prawdziwe wtedy i tylko wtedy, gdy Piotr jest filologiem.

31 Program semantyczny Davidsona daleki jest od zrealizowania. Na uwagę zasługuje jednak kilka rozwiązań szczegółowych, np. analiza parataktyczna zdań cudzysłowowych i zdań performatywnych. Polega ona na potraktowaniu wypowiedzenia, np. rozkazu „Czołgaj się do najbliższego drzewa”, jako pary wypowiedzeń zdań: „Następne wypowiedzenie jest rozkazem” i „Czołgasz się do najbliższego drzewa”. Każde z tych wypowiedzeń ma własne warunki prawdziwości w ramach teorii prawdy. Analizie parataktycznej poświęcone jest kilka artykułów w Davidson, 2001a, problem ten omawiam w Maciaszek, 2008, 409-457. Zastosowaniom analizy parataktycznej poświęcona jest również ostatnia monografia poświęcona Davidsonowi (zob. Lepore, Ludwig, 2007).

32 Teorię prawdy budujemy dla całego idiolektu, w tym miejscu podaję jedynie interesujące nas bezpośrednio reguly. 
T-zdania, wynikające z teorii prawdy, pozwalają testować teorię prawdy, np. konfrontując przekonania przypisywane interpretowanemu z przekonaniami interpretatora. Ponieważ teoria prawdy budowana jest dla całego idiolektu Jasia, wynika z niej nieskończenie wiele T-zdań. W szczególności, jeśli z innych, niepodanych tutaj reguł, które dotyczą zdań pojawiających się w dalszej części konwersacji, wynika podane niżej $T$-zdanie, to mamy do czynienia z kolejnym argumentem na rzecz utrzymania obecnej teorii prawdy.

5. Zdanie (Jasia) „Każdy filozof studiował teorię literatury” jest prawdziwe wtedy i tylko wtedy, gdy każdy filolog studiował teorię literatury.

Jeśli natomiast wynika z nich inne T-zdanie, to teorię prawdy należy zweryfikować.

6. Zdanie (Jasia) „Każdy filozof studiował teorię poznania” jest prawdziwe wtedy i tylko wtedy, gdy każdy filozof studiował teorię poznania.

W takim przypadku nowa teoria prawdy może przybrać postać podaną niżej.

II. Uznajemy, że Jaś jest przekonany o Piotrze (słusznie lub niesłusznie) ${ }^{33}$, że jest filozofem. W takim przypadku zmianie uległaby reguła (2):

7. Zdanie „a jest filozofem” jest spełnione przez ciąg $C$ wtedy i tylko wtedy, gdy obiekt przyporządkowany stałej $a$ przez $C$ jest filozofem.

$Z$ reguł semantycznych (1) i (7) oraz definicji prawdy (3) wynika:

8. Zdanie (Jasia) „Piotr jest filozofem” jest prawdziwe wtedy i tylko wtedy, gdy Piotr jest filozofem.

Nie jest to oczywiście jedyna możliwość. Konstruując dalej teorię prawdy, możemy bowiem przypisać Jasiowi przekonanie, że Piotr nigdy nie studiował filozofii, chociaż każdy filozof ją studiował. Aby uniknąć ewidentnej sprzeczności, otrzymujemy trzecią możliwość:

III. Uznajemy, że Jaś jest przekonany o Piotrze, że jest filologiem, ale konstruujemy teorię prawdy jak w punkcie (II), tj. uznajemy, że Jaś przypisuje słowu „filozof” takie samo znaczenie, jak my. W takim przypadku wkraczamy w obszar pragmatyki w sensie Davidsona. Wypowiedzenie „Piotr jest filozofem” potraktujemy jako kłamstwo, zart lub ironię.

Interpretując słowa drugiego człowieka, przypisujemy mu przekonania i jednocześnie konstruujemy teorię prawdy jego idiolektu, która pełni funkcję teorii znaczenia w tym sensie, że podaje znaczenia użytych przez niego wyrażeń poprzez przekład na nasz własny idiolekt. Jest to zatem teoria trzeciego typu. Nie musi to być, jak w naszym prostym przykładzie, przekład słowo na słowo. Znaczenia wyrażeń podaje bowiem cała teoria prawdy, nie zaś pojedyncze T-zdania. Zauważmy ponadto, że procedura interpretowania jest niezdeterminowana, gdyż zawsze istnieje wiele możliwości przypisania przekonań i znaczeń. Potraktowanie teorii prawdy jako teorii znaczenia budowanej w kontekście interpretacji słów drugiego człowieka stanowi jednocześnie propozycję uporania się z problemem wypowiedzeń niedosłownych. $\mathrm{Na}$ gruncie tej teorii nie ma miejsca na znaczenia niedosłowne, np. metaforyczne. Jednocześnie, w odróżnieniu od Wittgensteina, teoria Davidsona pozwala wyraźnie odróżniać użycie dosłowne od niedosłownego ${ }^{34}$.

33 Teoria prawdy Tarskiego nie rozstrzyga, czy zdanie jest faktycznie prawdziwe, lecz podaje jego warunki prawdziwości w metajęzyku.

34 Teoria metafory Davidsona (zob. Davidson, 1978) nosi nazwę niekognitywnej teorii metafory. Uogólnienie tej teorii na inne rodzaje wyrażeń niedosłownych przedstawiam w Maciaszek, 2008. 
Na zakończenie powróćmy do wprowadzonego przez Dummetta rozróżnienia na teorie umiarkowane i pełnokrwiste. W wielu artykułach Dummett — moim zdaniem bezpodstawnie ${ }^{35}$ — zarzuca teorii Davidsona, że nie jest w stanie wyjaśnić pojęć interpretowanego języka, o ile nie posiadają bezpośrednich odpowiedników w jego własnym idiolekcie. Teoria Davidsona jest, zdaniem Dummetta, jedynie pewną wersją teorii znaczenia opartej na przekładzie. Ponieważ teoria Quine’a jest teorią umiarkowaną, to jest nią również teoria Davidsona.

[...] umiarkowana teoria znaczenia nie daje nic więcej niż podręcznik przekładu, a wówczas nie wyjaśnia tego, co się wie znając język, albo musi być konstruowana holistycznie, w którym to przypadku jej pretensje do podania systematycznego wyjaśnienia znajomości języka są pozorne, gdyż holistyczna wizja języka wyklucza takie wyjaśnienie (zob. Dummett, 1993, 20).

Holistyczna teoria prawdy języka $J$ nie pozwala na wyjaśnienie znajomości języka, gdyż zdaniem Dummetta nie podaje kryteriów przyporządkowania zdaniom języka J właściwych im znaczeń. W szczególności wynikające z niej T-zdania nie pozwalają na takie przyporządkowanie, gdyż są, zdaniem Dummetta, zdaniami trywialnymi. Jak twierdzi Dummett, na gruncie pełnokrwistej teorii znaczenia, można dokonać rozróżnienia między brakiem zgody co do znaczenia zdania i brakiem zgody co do jego prawdziwości. Holistyczna teoria znaczenia Davidsona nie jest w stanie, jak twierdzi, takiego rozróżnienia dokonać, (zob. Dummett, 1993, 19). W rezultacie Dummett twierdzi, że teoria holistyczna może być jedynie pseudoteorią znaczenia (zob. Dummett, 1993, 21).

Zarzuty Dummetta skłoniły mnie do pewnej reinterpretacji teorii Davidsona. Polega ona na następującym spostrzeżeniu. W przypadku mojego własnego idiolektu teoria prawdy jest faktycznie trywialna — takie też są wynikające z niej T-zdania, np.:

9. (Moje zdanie) „Z” jest prawdziwe wtedy i tylko, gdy $Z$.

Zauważmy, że T-zdania wynikające z teorii prawdy budowanej dla idiolektu drugiego człowieka nie są już trywialne, nawet gdy Z1 i Z2 są równokształtne. 10. (Zdanie mojego rozmówcy) „Z1” jest prawdziwe wtedy i tylko, gdy Z2.

W przypadku mojego własnego idiolektu znaczenia wyrażeń konstytuowane są, podobnie jak w teorii Ajdukiewicza, przez układ przekonań, które jestem w stanie wyrazić w tym idiolekcie. Budując teorię prawdy idiolektu mojego rozmówcy oraz odtwarzając układ jego przekonań (wyrażony w moim własnym idiolekcie), buduję faktycznie teorię pełnokrwistą, w której jestem w stanie wyrazić pojęcia, które nie występują moim własnym idiolekcie i odróżnić przypisanie znaczeń od przypisania przekonań. Oczywiście na gruncie teorii holistycznej, która jest teorią trzeciego z wyróżnionych typów, nie jestem w stanie podawać znaczeń za pomocą zdań „Znaczeniem zdania „Z” jest to, i to” lub „Znaczeniem słowa „a” jest to i to”. Teoria taka nie zasługuje jednak z pewnością na miano „pseudoteorii”.

Przedstawione tu rozważania z pewnością nie wyczerpują tematu znaczenia i nie roszczą sobie prawa kompletności. Poruszają one jedynie jeden z problemów związanych ze znaczeniem — kształt teorii znaczenia, ale jak twierdzi M. Dummett (1993: 1):

35 Należy podkreślić, że później Dummet wycofał się częściowo ze swoich zarzutów. W tym miejscu odpieram zarzuty Dummetta w inny sposób. 
Zgodnie z pewnym ogólnie znanym poglądem, najlepsza metoda wyrażania filozoficznych problemów związanych ze znaczeniem i pojęciami pochodnymi polega na pytaniu o postać, którą powinna przybrać tzw. teoria znaczenia.

\section{Bibliografia}

Ajdukiewicz, K., 1960, Jezyk i poznanie, t. 1, Warszawa: Wydawnictwo Naukowe PWN. Burge, T.,2005, Truth, Though, Reason. Essays on Frege, Oxford: Clarendon Press.

Chomsky, N., 1959, A review of B. F. Skinner's 'Verbal Behavior', 'Language' 35, 26-58.

Church, A., 1951, The Need for Abstract Entities, 'American Academy of Arts and Sciences Proceedings' 80, 100-113 (przedruk pod tytułem Intensional Semantics [w:] A. P. Martinich, (red.) The Philosophy of Language, New York: Oxford University Press, 2001: 61-68).

Davidson, D., 1966, Theories of Meaning and Learnable Languages, 'Proceedings of the 1964 International Congress for Logic, Methodology and Philosophy of Science', Amsterdam: North Holland Publishing Co., 383-394 (przedruk [w:] Davidson, 2001a: 3-15).

Davidson, D., 1967, Truth and Meaning, 'Synthèse' 17, 304-23 (przedruk [w:] Davidson, 2001a, 17-36. Tłumaczenie polskie: Prawda i znaczenie, tł. J. Gryz, [w:] Davidson, 1992, 3-32).

Davidson, D., 1978, What Metaphors Mean, 'Critical Inquiry' 5, 31-47 (przedruk [w:] Davidson, 2001a, 245-264).

Davidson, D., 1992, Eseje o prawdzie, języku i umyśle, Warszawa: Wydawnictwo Naukowe PWN.

Davidson, D., 2001a, Inquiries into Truth and Interpretation, Oxford: Clerendon Press.

Davidson, D., 2001b, Subjective, Intersubjective, Objective, Oxford: Clerendon Press.

Dummett, M., 1973, Frege. Philosophy of Language, London: Duckworth.

Dummett, M., 1993, The Seas of Language, Oxford: Clarendon Press.

Frege, G., 1977, Pisma semantyczne, Warszawa: Wydawnictwo Naukowe PWN.

Hume, D., 1977, Badania dotyczace rozumu ludzkiego, Warszawa: Wydawnictwo Naukowe PWN.

Ingarden, R., 1960, O dziele literackim, Warszawa: Wydawnictwo Naukowe PWN.

Lepore, E., K. Ludwig, 2007, Donald Davidson's Truth-Theoretic Semantics, Oxford: Clarendon Press.

Locke, J., 1955, Rozważania dotyczace rozumu ludzkiego, t. 2, Warszawa: Wydawnictwo Naukowe PWN.

Maciaszek, J., 2008, Znaczenie, prawda, przekonania. Problematyka znaczenia w filozofii jezzyka, Łódź: Wydawnictwo Uniwersytetu Łódzkiego.

Mill, J. S., 1962, System logiki dedukcyjnej i indukcyjnej, t. 1, Warszawa: Wydawnictwo Naukowe PWN.

Quine, W. V. O., 1960, Word and Object, The Massachusetts Institute of Technology (tlumaczenie polskie Stowo i rzecz, tł. B. Stanosz, Warszawa: Fundacja Aletheia, Wydawnictwo Spacja, 1999).

Szlachcic, K. (red.), 1991, Pierre Duhema filozofia nauki. Wybór pism, Wrocław: Wydawnictwo Uniwersytetu Wrocławskiego.

Tarski, A., 1933, Pojęcie prawdy w jezykach nauk dedukcyjnych, „Prace Towarzystwa Naukowego Warszawskiego, nr 34, Warszawa (przedruk [w:] A. Tarski, Pisma logicznofilozoficzne, Warszawa: Wydawnictwo Naukowe PWN, 1995, 9-172).

Wittgenstein, L., 1921, Logisch-philosophische Abhandlung, „Annalen der Naturphilosophie, t. 14, s. 185-262 (wydanie polskie: Tractatus Logico-Philosophicus, tt. B. Wolniewicz, Warszawa: Wydawnictwo Naukowe PWN, 1997).

Wittgenstein, L., 1953, Philosophical Investigations, Oxford: Blackwel Publishing (wydanie polskie: Dociekania filozoficzne, tł. B. Wolniewicz, Warszawa: Wydawnictwo Naukowe PWN, 2000). 